Sebastian SOWA

\title{
Cywilizacyjne i technologiczne uwarunkowania kompetencji ortograficznej uczniów - wyniki badań empirycznych
}

\author{
Civilisational and Technological Determinants \\ of the Spelling Competence of the Student - \\ the Results of Empirical Research
}

\begin{abstract}
Su m mary: For a long time, didactics have been focusing attention to various factors that determine the effectiveness of teaching Polish spelling. The fullest description of the determinants of spelling competence was provided by Edward Polański in the 1970s. However, due to the development of civilisation and the cultural and technological changes at the turn of the 20th and 21st century, new factors that influence the student's correct spelling appeared (computers, smartphones, the Internet). Both linguists and educators noticed them. Therefore they postulated the need to diagnose the spelling skills of children and youth in the new civilisational-technological-information reality. It is just the results of such empirical research that I decided to examine in this article. The analysis of the respondents' writings proved that the computer and smartphone keyboard, and more generally - the excess of new technologies, has an impact on the student, especially on his mind.
\end{abstract}

Key words: spelling competence, spelling, ortogram, determinants, civilisational and technological determinants

Skuteczność nauczania polskiej ortografii zależy od wielu czynników ${ }^{1}$. Powszechnie wiadomo, że uczniowie wykazują duże rozbieżności w zakresie

${ }^{1} \mathrm{~W}$ artykule będą używane synonimy leksemu determinant, takie jak: czynnik, bodziec, uwarunkowanie. Wśród różnych czynników, od których zależy skuteczność nauczania polskiej ortografii, wyróżnić można: typ pamięci; zdolność logicznego myślenia; inteligencję; uwagę, 
uzdolnień i predyspozycji. Dydaktycy od dawna zwracali uwagę na różnorodne uwarunkowania i ich konsekwencje w procesie kształcenia wiedzy i umiejętności językowych. Najpełniej determinanty kompetencji ortograficznej opisał w latach siedemdziesiątych XX wieku Edward Polański². Jednakże w związku z rozwojem cywilizacji i zmianami kulturowymi oraz technologicznymi na przełomie XX i XXI wieku pojawiły się nowe czynniki wpływające na poprawny zapis - m.in. komputery, smartfony czy szeroko rozumiany Internet. Ich wpływ na język młodego pokolenia dostrzegli zarówno językoznawcy, jak i dydaktycy, którzy postulują potrzebę diagnozowania umiejętności ortograficznych dzieci i młodzieży w nowej rzeczywistości cywilizacyjno-technologiczno-informatycznej ${ }^{3}$.

Celem niniejszego artykułu jest nie tylko zwrócenie uwagi na szerokie spektrum bodźców decydujących o sprawności ortograficznej, ale również wyeksponowanie rezultatów kilkuetapowych własnych badań empirycznych. Miały one za zadanie potwierdzić założoną tezę lub zaprzeczyć jej: że związane z rozwojem cywilizacji nowo powstałe sprzęty elektroniczne wywierają szczególny wpływ na stan sprawności ortograficznej uczniów, podobnie jak pozostałe wcześniej zdiagnozowane - czynniki. Przeprowadzone analizy upoważniają mnie także do sformułowania wniosków i postulatów dydaktycznych.

Analiza uzyskanych wyników badań respondentów, skorelowana z założeniami teoretycznymi, miała przynieść odpowiedzi na cztery zasadnicze pytania: 1. Czy cywilizacyjne i technologiczne determinanty utrudniają (a nawet uniemożliwiają) uczniom kształcenie sprawności ortograficznej?

czyli kierowanie koncentracją; spostrzegawczość; płeć i wiek; frekwencję na lekcjach języka polskiego; czytelnictwo; znajomość reguł pisowni i gramatyki oraz umiejętność wykorzystywania ich w praktyce językowej; oceny z ćwiczeń ortograficznych i/lub interpunkcyjnych; świadomość znaczenia ortografii dla funkcjonowania społecznego; kształt i staranność pisma; powtórzenia materiału; zainteresowanie i motywację; elementy graficzne oraz barwy; korzystanie ze słowników ortograficznych; nowe uwarunkowania - cywilizacyjne i technologiczne: SMS-y, komunikatory elektroniczne, portale społecznościowe, klawiaturę komputera i smartfonu.

${ }^{2}$ Zob.: E. Polański: Badania nad ortografia uczniów. Katowice 1973; Idem: Dydaktyka ortografii i interpunkcji. Warszawa 1995; E. Polański, E. Dereń, A. Rychlik: Ortografia i interpunkcja w nauczaniu szkolnym i samokształceniu z ćwiczeniami. Kraków 2011.

${ }^{3}$ Zob. także publikacje autorów, którzy podejmują tematykę nowych mediów elektronicznych oraz ich wpływu na funkcjonowanie m.in. uczniów: Mediamorfozy. Red. T. Gackowski. Warszawa 2015; S. Kozak: Patologie komunikowania w Internecie. Zagrożenia i skutki dla dzieci i młodzieży. Warszawa 2011; Idem: Patologia fonoholizmu. Przyczyny, skutki i leczenie uzależnienia dzieci i młodzieży od telefonu komórkowego. Warszawa 2013; Idem: Patologia cyfrowego dzieciństwa i młodości. Przyczyny, skutki, zapobieganie w rodzinach i szkołach. Warszawa 2014; A. Ogonow ska: Uzależnienia medialne, czyli o patologicznym wykorzystaniu mediów i ich wplywie na nasze zdrowie oraz życie naszych dzieci. Kraków 2014; G. Sma11, G. Vorgan: iMózg. Jak przetrwać technologiczna przemianę wspótczesnej umysłowości. Tłum. S. Borg. Poznań 2011; M. Spitzer: Cyfrowa demencja. W jaki sposób pozbawiamy rozumu siebie i swoje dzieci. Tłum. A. Lipiński. Słupsk 2013. 
2. Czy używanie klawiatury komputera bądź smartfonu — zgodnie z założeniami teoretycznymi - rozleniwia pracę mózgu ucznia?

3. Czy użytkowanie nowych technologii skutkuje częstszymi błędami ortograficznymi, interpunkcyjnymi, literowymi oraz sprzyja praktykowaniu skrótów?

4. Czy prawdą jest, że język respondentów w komunikacji elektronicznej (w SMS-ach, komunikatorach elektronicznych, na portalach społecznościowych) cechuje się liczną modyfikacją zapisu wyrazów, powszechnym kodem ikonicznym (emotikonami), częstymi akronimami oraz spontanicznością przekazu?

\section{Narzędzia badawcze}

Badania przeprowadzone zostały w dwóch klasach licealnych w czerwcu oraz we wrześniu 2016 roku. Za podstawowe narzędzie badawcze przyjęto trzy rodzaje dyktand - papierowe (DP), papierowe wyboru (DPW) oraz elektroniczne (DE), czyli pisane na klawiaturze komputera ${ }^{4}$. Różne rodzaje dyktand miały na celu zbadanie nowych uwarunkowań kompetencji ortograficznej uczniów XXI wieku: wykazanie, z którym rodzajem dyktanda uczniowie radzą sobie najlepiej oraz zweryfikowanie założenia, że klawiatura komputera rozleniwia pracę mózgu, prowadząc tym samym do częstszych błędów, a także m.in. do obumierania szlaków pamięciowych i dekoncentracji ( $\mathrm{w}$ porównaniu do korzystnego wpływu pisania dyktanda za pomocą długopisu na tradycyjnej kartce papieru ${ }^{5}$ ). Ponadto

${ }^{4} \mathrm{~W}$ całym artykule stosowane będą jednakowe oznaczenia: skrót DP — dyktando papierowe (czyli pisane przez respondentów na tradycyjnej kartce papieru za pomocą długopisu); skrót DPW - dyktando papierowe wyboru (czyli respondenci dokonywali jedynie wyboru ortogramu spośród zaproponowanych przeze mnie odpowiedzi); skrót DE — dyktando elektroniczne (czyli pisane przez uczniów na klawiaturze komputera - precyzując — pisane w notatniku, żeby wyniki były rzetelne, a automatyczna korekta nie podkreślała respondentom błędnych form ortogramów).

${ }^{5}$ Ręczne pisanie ołówkiem, długopisem czy piórem ma pozytywny wpływ na mózg: mocniej aktywuje rejony czołowe kory mózgowej (odpowiedzialne za pamięć i przyswajanie nowych informacji), usprawnia pamięć, sprzyja kreatywności (bogatsze słownictwo w pracach pisanych ręcznie), stanowi o unikalności każdego ucznia (różne kroje pisma, pochylenia itd.), powoduje intensywniejszą pracę rejonów mózgu odpowiedzialnych za funkcje sensomotoryczne, czyli interpretację wrażeń dotykowych (także mocniej aktywizuje się tzw. ośrodek Broki), stymuluje rozwój rejonów mózgu odpowiedzialnych za rozpoznawanie liter i łączenie ich w słowa (u dzieci rozpoczynających dopiero naukę). Zob. K. Burda: O wyższości dtugopisu nad komputerem. „News- 
wśród respondentów została przeprowadzona ankieta na temat polskiej ortografii (A).

Kwestionariusz ankietowy składał się z dwóch części. Pierwsza część zawierała pytania zamknięte i otwarte, druga zaś — tylko zamknięte (wyboru wielokrotnego). Analiza pytań zamkniętych skorelowana z pytaniami otwartymi przyniosła zamierzone efekty badawcze. Wbrew powszechnym założeniom, że ankieta powinna być anonimowa, na potrzeby pracy badawczej, uczniowie zostali poproszeni, aby każdą z pisanych prac podpisali imieniem i nazwiskiem, co umożliwiło porównanie wszystkich prac poszczególnych respondentów i wyciągnięcie szczegółowych wniosków na temat nowych uwarunkowań sprawności ortograficznej w XXI wieku.

\section{Procedura badania}

Badania wśród respondentów prowadzone zostały z zachowaniem odstępów czasowych, w celu uzyskania bardziej rzetelnego materiału analitycznego. Każde z zadań (A, DP, DPW, DE) uczniowie realizowali na lekcjach — przede wszystkimjęzyka polskiego, a także zajęć informatycznych. Nauczyciel sprawujący opiekę nad uczniami był obecny podczas każdego typu badań. Uczniowie podeszli do prowadzonych badań odpowiedzialnie, uczciwie pracowali nad dyktandami i z ankietami. Najpierw respondenci wypełniali ankietę na temat polskiej ortografii. Następnie (w czerwcu 2016 roku) uczniowie pisali dyktando tradycyjne - długopisem na kartce papieru. Z kolei we wrześniu 2016 roku licealiści pisali w notatniku dyktowane przeze mnie dyktando na klawiaturze komputera ${ }^{6}$. Uczniowie nie mogli pisać prac w dokumencie Word, ponieważ otrzymane wyniki nie byłyby miarodajne: automatyczna korekta poprawiłaby im błędne formy ortogramów. Dyktando było odczytywane dwukrotnie. W trakcie drugiego czytania, stosując odpowiednią intonację, nauczyciel sygnalizował pojawiające się $\mathrm{w}$ tekście znaki przestankowania. Powinny zostać one uwzględnione przez uczniów w trakcie pisania prac. Każdy z respondentów po zakończeniu pisania przesłał e-mailem swoje dyktando prowadzącemu, a nauczyciel wydrukował uczniowskie prace. Tydzień później badani wypeł-

week" 2014, nr 49, s. 22. Zob. także: M. Spitzer: Ołówek czy klawiatura. W: Idem: Cyfrowa demencja..., s. 157-159.

${ }^{6} \mathrm{~W}$ celu łatwiejszego porównania wyników respondentów we wszystkich trzech rodzajach dyktand (DP, DPW, DE) wykorzystany został ten sam ułożony przeze mnie tekst. Tytuł dyktanda brzmiał: Kaktusówka, czyli żywot małego niepospolitego ptaszka o lekko brązowym upierzeniu. 
niali dyktando papierowe wyboru, w którym mieli zaznaczyć 28 poprawnych form. Był to ostatni typ zadania, z którym pracowali uczniowie.

Fazy pisania prac przez respondentów można więc przedstawić następująco:

ankieta na temat polskiej ortografii (A) $\rightarrow$ dyktando papierowe (DP) $\rightarrow$

$\rightarrow$ dyktando elektroniczne (DE) $\rightarrow$ dyktando papierowe wyboru (DPW)

\section{Wyniki analizy materiału badawczego}

Dzisiejsza młodzież ${ }^{7}$ żyje w dobie szybko postępującej digitalizacji społeczeństwa, dąży do uproszczonego porozumiewania się, ekonomizacji wysiłku i oszczędnego operowania środkami językowymi ${ }^{8}$. To oczywiste, że

życie bez komputera, smartfonu czy Internetu obecnie jest już niemożliwe. Dzieci i młodzież spędzają dziś w świecie cyfrowych mediów ponad dwa razy więcej czasu niż w szkole. Skutkami są zakłócenia rozwoju mowy, problemy z nauką i koncentracją, stres, depresja i narastająca gotowość do stosowania przemocy fizycznej'.

Właśnie dlatego w hierarchii determinantów, które obecnie wpływają na sprawność ortograficzną, najwyższą pozycję zajmują uwarunkowania cywilizacyjne i technologiczne, czyli nowe technologie.

Analiza przeprowadzonych przeze mnie trzech odmian dyktand dostarczyła m.in. danych o wpływie pisania na komputerze czy też smartfonie na procesy myślowe uczniów, w tym na ich koncentrację, pamięć czy spostrzegawczość.

${ }^{7}$ Dla młodych ludzi urodzonych po 1980 roku smartfony, tablety, komputery, dostęp do Internetu są tak oczywistymi elementami świata, jak dla pokolenia rodziców, a często także dziadków dzisiejszej młodzieży, radio i telewizja. Przyjęły się różne wyrażenia określające młodych ludzi, którzy sprawnie posługują się nowymi technologiami i nieustannie z nich korzystają. Najczęściej pojawiające się w obiegu nazwy to: cyfrowi tubylcy, pokolenie po 1980 roku, pokolenie milenium, generacja Y (w odróżnieniu od generacji X, czyli ludzi urodzonych w latach 1965-1980), generacja sieci, generacja Z, pokolenie Google'a, dzieci sieci (tzw. sieciaki), użytkownicy w sieci (tzw. sieciuchy) - nazwy zazwyczaj pejoratywnie nacechowane. Por.: S. Kozak: Patologie komunikowania..., s. 60-61.

${ }^{8}$ D. Krzyżyk, H. Synowiec: $O$ (nie)obecności ortografii $w$ podręcznikach szkolnych. W: Polonista dziś. Kształcenie dla jutra. T. 3. Kraków 2014, s. 94-95.

${ }^{9}$ Zob.: M. Spitzer: Cyfrowa demencja..., s. 157-161. 
Także w kwestionariuszu ankiety wybrane ${ }^{10}$ zadania dotyczyły cywilizacyjnych i technologicznych uwarunkowań XXI wieku.

$\mathrm{Z}$ treści dyktanda zostało wybranych łącznie 28 ortogramów ${ }^{11}$, które zostały poddane analizie. W dyktandach sprawdzana była znajomość różnych reguł ortograficznych, m.in. dotyczących pisowni wielką i małą literą; zapisu partykuły nie z różnymi częściami mowy; zapisu połączeń wyrazowych z członami niby-, quasi-; zapisu przymiotników złożonych z dwóch członów równorzędnych znaczeniowo; użycia łącznika; zapisu wyrazów pospolitych czy zapisu przedrostków.

Aż 36 na 40 respondentów w wersji papierowej dyktanda zapisało poprawnie więcej ortogramów niż na klawiaturze komputera lub uzyskało identyczny wynik. Warto zwrócić uwagę, że występuje przewaga prawidłowego zapisu ortogramów w dyktandzie papierowym — zdarza się, że jest to siedem czy nawet osiem punktów więcej niż w dyktandzie elektronicznym. Za przykład posłużyć mogą wybrane prace (por. tabela 1$)^{12}$.

Przeprowadzona analiza potwierdza więc założenia badawcze mówiące o negatywnym wpływie klawiatury komputera — na nauczanie polskiej ortografii i proces jej reprodukcji ${ }^{13}$. W napisanych przez respondentów dyktandach elektronicznych o wiele częściej pojawiają się niepoprawne zapisy — błędy ortograficzne, interpunkcyjne, często pomijane są znaki diakrytyczne ${ }^{14}$ (co w wersji papierowej dyktanda praktycznie nie występuje), dość liczne są także błędy literowe. W dyktandach elektronicznych licealiści chętniej stosują również skróty ${ }^{15}$.

${ }^{10}$ Mowa jest o wybranych zadaniach, ponieważ w ankiecie znalazły się także inne pytania, które miały zdiagnozować pozostałe uwarunkowania sprawności ortograficznej uczniów. W artykule nie odnoszę się do tego materiału.

${ }^{11}$ Lista ortogramów wykorzystanych w badaniu (podaję w formach, które wystąpiły w dyktandzie): nie za dobrze, nie najlepsze, nie najszczęśliwiej, niedobrze, niby-ptak, brąowoszary, dalekowidzacymi, pótnocny Meksyk, południowa Amerykę Pótnocna, biało-czerwonej, Polski, pót-Meksykanka, pót-Amerykanka, Tucholskiego Parku Krajobrazowego, szyi, stopni, mikołajek, świąt Bożego Narodzenia, Świąt Wielkanocnych, święta 3 Maja, nie lada, dwudziestotrzyipółletni, mszysto-porostowa, wszystkowidzacej, wszystkowiedzacej, po prostu, nierzadko, pokrótce.

${ }_{12}$ Dane statystyczne z przeprowadzonych przeze mnie badań.

${ }^{13}$ Neurolingwiści alarmują, że używanie nowych sprzętów elektronicznych ma negatywny wpływ na nauczanie (polskiej ortografii), gdyż pisanie na klawiaturze po pierwsze rozleniwia pracę mózgu ucznia, po drugie — prowadzi do szeregu zmian w strukturze sieci neuronalnej, a po trzecie - osłabia koncentrację uwagi i obniża skuteczność działania. Por.: M. Spitzer: Cyfrowa demencja..., s. 157-161.

${ }^{14}$ W 55\% prac respondenci nie zaznaczyli w piśmie nosowości głosek $(a, e)$ lub zapominali o ich regularnym stosowaniu.

${ }^{15}$ Skróty stosowane przez respondentów w elektronicznej wersji dyktanda: $s b$ (zamiast: $s o$ bie); $k$ g (zamiast: kilograma); 23,5-letni, 23 i pół letni, 23 i pólletni, 23 i 1/2 letni (zamiast: dwudziestotrzyipółletni); F. Dostojewskiego (zamiast: Fiodora Dostojewskiego); 3-ujka (zamiast: trójka); św. (zamiast: świat); 1/2 metrowa, 0,5m (zamiast: pótmetrowa); 1/2, 0,5 (zamiast: pót); pt. (zamiast: pod tytułem). 
Wyniki uzyskane przez respondentów w trakcie pisania dyktanda papierowego (DP) oraz dyktanda elektronicznego (DE)

\begin{tabular}{|c|c|c|}
\hline Uczeń & DP - liczba punktów & DE - liczba punktów \\
\hline $\mathbf{1 .}$ & $22 / 28$ & $18 / 28$ \\
\hline $\mathbf{2 .}$ & $21 / 28$ & $15 / 28$ \\
\hline $\mathbf{3 .}$ & $20 / 28$ & $15 / 28$ \\
\hline $\mathbf{4 .}$ & $19 / 28$ & $14 / 28$ \\
\hline $\mathbf{5 .}$ & $18 / 28$ & $14 / 28$ \\
\hline $\mathbf{6 .}$ & $18 / 28$ & $10 / 28$ \\
\hline $\mathbf{7 .}$ & $16 / 28$ & $12 / 28$ \\
\hline $\mathbf{8 .}$ & $16 / 28$ & $11 / 28$ \\
\hline $\mathbf{9 .}$ & $16 / 28$ & $11 / 28$ \\
\hline $\mathbf{1 0 .}$ & $15 / 28$ & $11 / 28$ \\
\hline $\mathbf{1 1 .}$ & $15 / 28$ & $9 / 28$ \\
\hline $\mathbf{1 2 .}$ & $15 / 28$ & $8 / 28$ \\
\hline $\mathbf{1 3 .}$ & $14 / 28$ & $10 / 28$ \\
\hline $\mathbf{1 4 .}$ & $14 / 28$ & $9 / 28$ \\
\hline $\mathbf{1 5 .}$ & $14 / 28$ & $9 / 28$ \\
\hline $\mathbf{1 6 .}$ & $13 / 28$ & $9 / 28$ \\
\hline $\mathbf{1 7 .}$ & $13 / 28$ & $7 / 28$ \\
\hline
\end{tabular}

Źródło: Opracowanie własne.

Operowanie przez młodych użytkowników języka środkami charakterystycznymi dla kodu ograniczonego (skrótami i skrótowcami) wynika z kilku czynników, wśród których wymienić można:

- modę na bylejakość pisania;

- modę na wszechobecny luz (nie tylko w języku, ale i w zachowaniu);

- postawę sprzeciwu wobec starszych;

- chęć do upraszczania wszystkiego (bierność intelektualna);

- wpływ środków masowego przekazu, także Internetu, i propagowanych przez nie wzorców językowych ${ }^{16}$.

Przyjrzyjmy się rezultatom analiz (por. tabela 2 ) $^{17}$. Na podstawie zebranego materiału ustalono, że najlepiej z dyktandem wyboru poradzili sobie chłopcy

${ }^{16}$ Por:: K. Ożóg: Polszczyzna przełomu XX i XXI wieku. Wybrane zagadnienia. Rzeszów 2007, s. 181.

${ }^{17} \mathrm{~W}$ tabeli zestawiono prace czterdziestu uczniów, z wyodrębnieniem dziewcząt i chłopców, którzy napisali wszystkie trzy rodzaje dyktand (DP, DPW, DE). Umieszczone w tabeli wartości - dla dziewcząt: 255, 308, 299, dla chłopców: 230, 290, 301, odnoszą się do liczby poprawnie zapisanych ortogramów przez uczestników badania (z podziałem na płeć). 
(średnia tego pomiaru wyniosła aż 15,05 ortogramów zapisanych poprawnie), dziewczęta zaś - minimalnie lepiej z wersją papierową dyktanda (tutaj średnia wyniosła 15,4). Najsłabiej napisane przez respondentów zostało dyktando elektroniczne - średnia u chłopców to zaledwie 11,5, a u dziewcząt niewiele więcej, bo 12,75 .

Podczas pisania dyktanda tradycyjną metodą uczniowie koncentrują uwagę na tekście, skupiają myśli i — najprościej mówiąc — analizują to, co piszą. Dzięki temu unikają pomyłek i błędów. Natomiast pisanie pracy na komputerze powoduje u nich dekoncentrację i spowolnienie działania szlaków pamięcio$\mathrm{wych}^{18}$. Respondenci są rozkojarzeni i bez zastanowienia „stukają” w klawisze, co w efekcie skutkuje większą liczbą błędów. Dobre wyniki, które badani (zarówno dziewczęta, jak i chłopcy) osiągnęli, pracując nad dyktandem papierowym wyboru, mogą świadczyć o przyzwyczajeniu młodych Polaków do rozwiązywania zadań testowych (w tym zadań z lukami i zadań wielokrotnego wyboru). Uzyskane wyniki mogą również sugerować dominację u respondentów pamięci wzrokowej ${ }^{19}$ - gdy widzą oni zapis kilku wariantów ortogramu, potrafią, dzięki analizatorowi wzroku, wskazać ten prawidłowy.

Tabela 2

Wyniki uzyskane na podstawie pracy z różnymi rodzajami dyktand

\begin{tabular}{|c|c|c|}
\hline Rodzaj dyktanda & Dziewczęta (20) & Chłopcy (20) \\
\hline DE & $255: 20=\mathbf{1 2 , 7 5}$ & $230: 20=\mathbf{1 1 , 5}$ \\
\hline DP & $308: 20=\mathbf{1 5 , 4}$ & $290: 20=\mathbf{1 4 , 5}$ \\
\hline DPW & $299: 20=\mathbf{1 4 , 9 5}$ & $301: 20=\mathbf{1 5 , 0 5}$ \\
\hline
\end{tabular}

Źródło: Opracowanie własne.

W celu uzyskania bardziej szczegółowego materiału empirycznego na temat cywilizacyjnych i technologicznych determinantów w kwestionariuszu ankietowym umieszczono polecenie polegające na napisaniu SMS-a do kolegi lub koleżanki z informacją o spóźnieniu na umówione spotkanie. Wypowiedź miała zawierać następujące elementy:

${ }_{18}$ Por. siedem grzechów pamięci według Daniela Schactera: nietrwałość, roztargnienie, blokowanie, błędne atrybucje, podatność na sugestię, tendencyjność i uporczywość. Zob. D.L. Schacter: Siedem grzechów pamięci. Jak zapominamy i zapamiętujemy. Tłum. E. Haman, J. Rączaszek. Warszawa 2003. Na temat pamięci oraz szlaków pamięciowych pisał znany amerykański psycholog Philip Zimbardo. Zob. P.G. Zimbard o: Pamięć. W: Psychologia. Kluczowe koncepcje. Red. M. Materska. T. 2. Warszawa 2010, s. 225-238.

19 Omawiając istotę pamięci, dydaktycy biorą pod uwagę analizator, przez jaki napływa dana informacja. Wyróżniają cztery podstawowe typy pamięci: pamięć wzrokową, słuchową, motoryczną (kinestetyczną czy po prostu ruchową), emocjonalną. Por.: D. Krzyżyk: Uczeń w krainie ortografii. W: D. Bula, D. Krzyżyk, B. Niesporek-Szamburska, H. Synowiec: Dziecko w'świecie języka. Kraków 2004, s. 211-212. 
— przywitanie/pożegnanie kolegi/koleżanki;

— powiadomienie o spóźnieniu (ewentualnym czasie opóźnienia);

— powód niepunktualności;

- krótkie przeprosiny.

Respondenci zostali poproszeni o zapisanie wiadomości tak, jakby odtwarzali pisanie na klawiaturze telefonu komórkowego. Pod poleceniem ankietowym, żeby ułatwić badanym wejście w daną sytuację, została umieszczona ilustracja imitująca okno wiadomości SMS na smartfonie. Zaproponowane zadanie miało na celu zbadanie, czy uczniowie przyzwyczajeni są do wysyłania zwięzłej wiadomości, czy potrafią krótko i na temat napisać treść SMS-a oraz czy respektują $\mathrm{w}$ tworzonej wiadomości m.in. reguły ortograficzne i reguły interpunkcyjne. Okazało się, że większość uzyskanych odpowiedzi charakteryzuje się skrótowością ${ }^{20}$. Najkrótsze zdanie, które zawiera - co ciekawe - wszystkie wymagane elementy brzmiało: Yo spoznie się bo korki sry; $c^{21}$. Gdzie: Yo - powitanie (tzw. jot); spoznie się — powiadomienie o spóźnieniu; bo korki, czyli podanie powodu niepunktualności (korki w znaczeniu 'korek drogowy'); sry jako przeprosiny (z ang. sorry — przepraszam). Na końcu wiadomości pojawił się jeszcze tzw. emotikon (element kodu ikonicznego) ${ }^{22}$ oznaczający smutek: ;c.

Inne wypowiedzi respondentów również miały skrótową formę, a zapis nie był wolny od różnego typu błędów i usterek, por.:

- A.G.: hej spoznie się, autobus uciekl sorki;

- K.M.: siema spoznie sie na spotkanie miatem dodatkowe lekcje sorki;

- K.P1.: No elo. Trochę się spóźnię, muszę pomóc mamie w domu, sorry kumpel;

- K.W1.: Hej hoo! Rybko uciekt mi autobus, chwilkę się spóźnie. Przepraszam ale za późno wyszłam z domu. Ciao;

- N.W.: Hej, sorka ale spóznie się trochę (!) bo sa korki;

- W.R.: Siemka. Ja spóźnię się około 10 min. Sorki bo musiałem wyjść z psem :\% Analiza materiału z tego zadania pozwala wyciągnąć wnioski, że młodzież, korzystająca powszechnie z nowych technologii, jest przyzwyczajona do krót-

20 Jan Grzenia wśród skrótów internetowych wyodrębnia ucięcia, pośród których można wyróżnić takie, które zostały przejęte z mowy potocznej lub powstały bezpośrednio w Internecie (np. nara 'na razie', $p z d r$ 'pozdrowienia', spoko 'spokojnie') oraz akronimy, czyli najczęściej skróty rozbudowanych wyrażeń wywodzące się z języka angielskiego (np. $Z W$ 'zaraz wracam', $L O L$ 'laughing out loud, wyśmiewając głośno', THX 'thanks, dzięki'). Zob. J. Grzenia: Komunikacja językowa w Internecie. Warszawa 2006, s. 145-149.

${ }^{21}$ Odpowiedź ankietowanego K.K. We wszystkich cytowanych w artykule odpowiedziach respondentów zachowano oryginalną pisownię.

${ }^{22}$ Emotikony zastępują słowa - są tekstami, które stanowią próbę naśladowania naturalnego kontaktu „twarzą w twarz”. Są to „kombinacje znaków nieliterowych o prymarnej funkcji, jaką jest powiadamianie według zasad określonego kodu". Inne synonimiczne pojęcia do słowa emotikon to: naklejka, nalepka, buźka, uśmieszek czy minka. Por.: J. Grzenia: Komunikacja językowa..., s. 119-124. 
kich i zwięzłych form wypowiedzi, co odzwierciedla tendencję do ekonomizacji języka - dążenie do przekazania maksimum informacji (wiedzy) przy minimum słów. Oprócz akronimów w pracach licealistów pojawiło się pięć różnych emotikonów, które wyrażają emocje nadawcy komunikatu (mimikę, intonację głosu, gestykulację i nastrój):

$$
:(:) ; * ;
$$

W wypowiedziach uczniów występują liczne modyfikacje zapisu wyrazów ${ }^{23}$. Odnotowano m.in. zwielokrotnianie liter jako wyraz ekspresji głosowej (np. Eloo, Hej hoo), niestosowanie wielkich liter zgodnie z przepisami ortograficznymi lub niekonsekwentne ich używanie (np. siema spoznie się na spotkanie miałem dodatkowe lekcje sorki), nieprzestrzeganie pisowni łącznej i rozdzielnej (np. wogóle), pomijanie znaków diakrytycznych (np. spóznie, spoznie, uciekl), tworzenie skrótów (np. sry, elo).

Respondenci zostali również poproszeni o rozszyfrowanie treści wiadomości, w której użyte zostały doraźnie utworzone skróty, wyrazy bez koniecznych znaków diakrytycznych, akronimy. Musieli przepisać wiadomość, nanosząc poprawki, także ortograficzne i interpunkcyjne. Zadanie to miało sprawdzić, jak uczestnicy badania poradzą sobie z odczytaniem przesłanego SMS-a, czy zastosowane zabiegi wpłyną na jakość odczytań. Oto treść wiadomości, jaką otrzymali ankietowani, oraz jej poprawna wersja:

cze iwo pilnie musze leciec na kolosa z matmy. tak sie boje ze az lek paralizuje moje myslenie.

bd wdziczna jesli pżekarzesz to info mami! wroce około 4tej 3maj sie i wstaf jesce pranie zciemnym — ,thx!!!!!! (2) A! moze jak wroce obejrzymy film o drugim kacie

Cześć Iwona. Pilnie muszę iść (lecieć) na kolokwium z matematyki. Tak się boję, że aż lęk paraliżuje moje myślenie. Będę wdzięczna, jeśli przekażesz tę informację mamie! Wrócę około czwartej. Trzymaj się i wstaw jeszcze pranie z ciemnym (ciemnymi ubraniami) — dziękuję!

(:) A! Może, jak wrócę, obejrzymy film o drugim kacie.

${ }^{23}$ Respondenci okazują się w tym względzie kreatywni, a ich twórczość nie zna granic. Zob. ibidem. Zob. także: W. Lubaś: Polska pisownia w Internecie, prestiż oficjalnej ortografii i jej nauczanie. W: „Z Teorii i Praktyki Dydaktycznej Języka Polskiego”. T. 18. Red. H. Synowiec. Katowice 2005, s. 96-108. Władysław Lubaś podaje również cechy języka w przestrzeni komunikacji internetowej (na podstawie obserwacji czatów, portali społecznościowych, blogów i e-maili). Wśród nich wymienia (dodatkowo oprócz zauważonych przez Grzenię) m.in.: uwalnianie się od znaków diakrytycznych (np. dostanom kare na ziemi...); ożywianie liter niefunkcjonalnych w oficjalnej ortografii $(X, Q)$; wprowadzanie pisowni fonetycznej (np. Pozdrooofki lub hiperpoprawne naprafde); wprowadzanie cyfr i liter spoza polskiego zasobu (np. w moim wieq; $q=k u$ ). 
Odpowiedzi respondentów dostarczyły ciekawego materiału badawczego, który można podsumować następująco: używanie wszelkiego rodzaju skrótów, skrótowców, ucięć, akronimów przyspiesza proces komunikacji, ale niejednokrotnie prowadzi również do dwuznaczności (komunikaty mogą być różnie odczytane, nie zawsze zgodnie z intencją nadawcy). Na przykład jeden z uczniów zamiast rozszyfrować skrót: około 4tej 3maj się - około czwartej, trzymaj się, zrozumiał - około czwartej trzeciego maja. Sytuacja ta może wydawać się komiczna, ale nowe technologie, wymuszane niejako przez szybkie tempo życia, mogą prowadzić do znacznie poważniejszych nieporozumień ${ }^{24}$. Dlatego bardzo ważne w procesie edukacji jest to, by uświadamiać uczniom konsekwencje ekonomizacji języka, luzu językowego czy bylejakości redagowanych komunikatów.

Odpowiedzi udzielone na cztery pytania o rozstrzygnięcie ${ }^{25}$ pozwoliły określić stopień świadomości językowo-komunikacyjnej respondentów, a zarazem ich stosunek do języka ojczystego. Spośród ankietowanych 58\% zadeklarowało, że przestrzega reguł polskiej ortografii i interpunkcji, pisząc SMS-y do kolegi lub koleżanki; $52 \%$ respondentów twierdzi, że używa znaków diakrytycznych, a $42 \%$ deklaruje, że ich nie uwzględnia; $69 \%$ badanych nie ma trudności ze zrozumieniem sensu wiadomości, która zapisana jest bez znaków diakrytycznych. I wreszcie - 48\% licealistów przyznaje, że zwraca uwagę drugiej osobie, jeżeli ta popełniła błąd w wiadomości przesyłanej za pośrednictwem komunikatora elektronicznego czy w tekście zamieszczonym na portalu społecznościowym; $44 \%$ twierdzi, że tego nie robi. Trzeba jednak pamiętać, by do opinii respondentów podchodzić ostrożnie, ponieważ ich deklaracje mogą być odmienne od stanu faktycznego. Wśród badanych znalazły się bowiem i takie osoby, które w ankiecie zaznaczyły, że przestrzegają zasad ortografii i używają znaków diakrytycznych, a w ich dyktandzie — papierowym lub elektronicznym — ta deklaracja nie potwierdziła się ${ }^{26}$.

24 Świadomość znaczenia ortografii dla funkcjonowania społecznego trzeba uznać za kolejny ważny determinant kompetencji ortograficznej uczniów. W polszczyźnie istnieją wyrazy, których znaczenie — poza pisownią — różnicuje kontekst. Leksemy można także odróżnić, kierując się wiedzą z zakresu fleksji, por. konstrukcje: brak mu hartu (ducha) oraz brak mu charta (rasy psa). Ponadto niektóre ortogramy różnicuje wielka lub mała litera, np. Na głowie mam teraz Chetm (czyli wyjazd do Chełma) i zdanie Przecież nie masz hełmu (w sensie na głowie). Zob. także: E. Polański: O polskiej ortografii i interpunkcji dzisiaj — ze szczypta humoru. Komunikacyjna skuteczność a poprawność. W: Żonglowanie słowami. Językowy potencjat a manifestacje tekstowe. Red. M. Kita. Katowice 2006, s. 203-206.

${ }^{25}$ Pytania te miały postać: Czy przestrzegasz regut polskiej ortografii i interpunkcji, piszac SMS do kolegi lub koleżanki?; Czy pisząc SMS, używasz znaków diakrytycznych (kropki, kreski, ogonki etc.), np. zapisujesz: męża, później, a nie meza, pozniej?; Czy masz kłopot ze zrozumieniem sensu wiadomości, w których wyrazy sa zapisywane z pominięciem znaków diakrytycznych?; Czy zwracasz uwage osobie, która popetnita błąd ortograficzny lub interpunkcyjny w SMS-ie, e-mailu, na portalu społecznościowym (typu: Facebook)?.

${ }^{26}$ Zdarza się, że w pracach uczniowskich występują rozbieżności między tym, co deklarowane, a stanem faktycznym. 
Z przeprowadzonych analiz wynika, że uczniowie nie zdają sobie sprawy z roli znaków diakrytycznych, a przecież błędna ortografia i interpunkcja powoduje - przypomnę - zakłócenia komunikacyjne. W polszczyźnie istnieją takie wyrazy, których zapis różnicowany jest jedynie przez kontekst. Należy więc uwrażliwić uczniów na to, że nie wolno rezygnować ze znaków diakrytycznych i trzeba respektować zasady polskiej ortografii oraz interpunkcji w tekstach, takich jak e-maile, SMS-y, a także tych zamieszczanych na portalach społecznościowych i przesyłanych za pośrednictwem komunikatorów elektronicznych. Należy ponadto uzmysłowić wychowankom, że automatyczna korekta nie zwalnia nadawcy komunikatu ze znajomości reguł ortograficznych i interpunkcyjnych oraz śledzenia poprawności zapisu wyrazów (np. w dokumencie Word).

$\mathrm{W}$ obecnej sytuacji łatwego dostępu do Internetu nauczyciele i rodzice powinni dbać o to, by dzieci korzystały z niego racjonalnie. Stały kontakt z nowymi sprzętami technologicznymi powoduje bowiem zakłócenia w koncentracji, a przecież właśnie koncentracja uwagi i spostrzegawczość to dwa ważne bodźce wpływające na poprawność zapisu. Uczeń najpierw musi spostrzec zjawisko, by potem móc skoncentrować na nim uwagę (np. na konkretnym ortogramie czy regule ortograficznej). Prowadzący zajęcia powinien więc dążyć do skupienia uwagi uczniów - kierować nią tak, by efektywniej osiągać zamierzone cele zajęć.

Mimo że badania empiryczne potwierdzają negatywny wpływ nowoczesnych technologii na sprawność ortograficzną uczniów, uważam, że nauczyciele nie powinni jednak rezygnować z sięgania po nie na lekcjach, mogą np. korzystać z prezentacji multimedialnych, przyciągających uwagę uczniów. Mogą również prosić podopiecznych, by poszukali określonych informacji w sieci, ucząc jednocześnie krytycznej ich oceny oraz selekcji znalezionych danych. Internet jest bowiem cennym źródłem wiedzy, ale tylko wtedy, gdy potrafi się z niego rozsądnie korzystać.

Wyniki badań nad nowymi determinantami sprawności ortograficznej uczniów upoważniają mnie do sformułowania wskazówek dla nauczycieli. Dla jednoznaczności została im nadana forma dyrektywna. Oto ujęte w punkty trzy najważniejsze dezyderaty dla nauczycieli:

1. Uczulaj młode pokolenie, że czynniki cywilizacyjno-techniczne oddziałują negatywnie - wpływają na nasz język, także poprawność ortograficzną.

2. Uświadamiaj uczniom, że korzystanie ze sprzętów elektronicznych i dołączonych do nich programów narzędziowych nie zapobiega powstawaniu błędów - nie zastąpią one wiedzy ortograficznej i nawyków poprawnego pisania.

3. Stosuj na zajęciach nowe technologie - nie rezygnuj z nich, ale czyń to z rozsądkiem i umiarem. 


\section{Bibliografia}

Burda K.: O wyższości dtugopisu nad komputerem. „Newsweek” 2014, nr 49.

Grzenia J.: Komunikacja językowa w Internecie. Warszawa 2006.

Kozak S.: Patologia cyfrowego dzieciństwa i młodości. Przyczyny, skutki, zapobieganie w rodzinach $i$ szkołach. Warszawa 2014.

Kozak S.: Patologia fonoholizmu. Przyczyny, skutki i leczenie uzależnienia dzieci i młodzieży od telefonu komórkowego. Warszawa 2013.

Kozak S.: Patologie komunikowania w Internecie. Zagrożenia i skutki dla dzieci i młodzieży. Warszawa 2011.

Krzyżyk D.: Uczeń w krainie ortografii. W: D. Bula, D. Krzyżyk, B. Niesporek-Szamburska, H. Synowiec: Dziecko w świecie języka. Kraków 2004.

Krzyżyk D., Synowiec H.: O (nie)obecności ortografii w podręcznikach szkolnych. W: Polonista dziś. Ksztatcenie dla jutra. T. 3. Kraków 2014.

Lubaś W.: Polska pisownia w Internecie, prestiż oficjalnej ortografii i jej nauczanie. W: „Z Teorii i Praktyki Dydaktycznej Języka Polskiego”. T. 18. Red. H. Synowiec. Katowice 2005.

Mediamorfozy. Red. T. Gackowski. Warszawa 2015.

Ogonowska A.: Uzależnienia medialne, czyli o patologicznym wykorzystaniu mediów i ich wplywie na nasze zdrowie oraz życie naszych dzieci. Kraków 2014.

Ożóg K.: Polszczyzna przełomu XX i XXI wieku. Wybrane zagadnienia. Rzeszów 2007.

Polański E.: Badania nad ortografia uczniów. Katowice 1973.

Polański E.: Dydaktyka ortografii i interpunkcji. Warszawa 1995.

Polański E.: O polskiej ortografii i interpunkcji dzisiaj-ze szczyptą humoru. Komunikacyjna skuteczność a poprawność. W: Żonglowanie słowami. Językowy potencjat a manifestacje tekstowe. Red. M. Kita. Katowice 2006.

Polański E., Dereń E., Rychlik A.: Ortografia i interpunkcja w nauczaniu szkolnym i samokształceniu z ćwiczeniami. Kraków 2011.

Schacter D.L.: Siedem grzechów pamięci. Jak zapominamy i zapamiętujemy. Tłum. E. Haman, J. Rączaszek. Warszawa 2003.

Small G., Vorgan G.: iMózg. Jak przetrwać technologiczna przemianę współczesnej umysłowości. Tłum. S. Borg. Poznań 2011.

Spitzer M.: Cyfrowa demencja. W jaki sposób pozbawiamy rozumu siebie i swoje dzieci. Tłum. A. Lipiński. Słupsk 2013.

Spitzer M.: Ołówek czy klawiatura. W: Idem: Cyfrowa demencja. W jaki sposób pozbawiamy rozumu siebie i swoje dzieci. Tłum. A. Lipiński. Słupsk 2013.

Zimbardo P.G.: Pamięć. W: Psychologia. Kluczowe koncepcje. Red. M. Materska. T. 2. Warszawa 2010. 